\title{
Reaction of Cultivar Coffee 'Vitória INCAPER 8142' of Cornillon to Parasitism of Meloidogyne exigua
}

\author{
Reacción del Cultivar de café 'Vitória INCAPER 8142' \\ de Cornillon al parasitismo de Meloidogyne exigua \\ Cristiano C. Contarato ${ }^{1}$, Marcelo A. Tomaz ${ }^{1}$, Fábio R. Alves ${ }^{1 *}$, Fabrício M. Sobreira ${ }^{1}$, \\ Waldir C. de Jesus Junior ${ }^{1}$, Lilian K.C. Rabello ${ }^{1}$, Maria A.G. Ferrão ${ }^{2}$, Romário G. Ferrão ${ }^{2}$
}

\begin{abstract}
Among factors limiting to the yield of the coffee crop are the diseases, deserving prominence the nematode Meloidogyne exigua. The objective of this work was to assess the level of resistance of 13 clones $(1 \mathrm{~V}, 2 \mathrm{~V}, 3 \mathrm{~V}, 4 \mathrm{~V}, 5 \mathrm{~V}, 6 \mathrm{~V}, 7 \mathrm{~V}, 8 \mathrm{~V}, 9 \mathrm{~V}, 10 \mathrm{~V}, 11 \mathrm{~V}, 12 \mathrm{~V}$ and $13 \mathrm{~V}$ ) wich composes the clonal variety 'Vitória INCAPER 8142' of conilon coffee (Coffea canephora Pierre), to M. exigua. The 13 clones and more one control (C. arabica, cv. Catuaí IAC-44) were inoculated with 7,000 individuals of M. exigua. After 180 days of inoculation, the final population of nematodes per root system was determined. For determination of the resistance levels, both the reproduction factor and the reduction of the reproduction factor were considered. The variety 'Vitória INCAPER 8142 ' presented clones with different levels of resistance. Clones $1 \mathrm{~V}, 4 \mathrm{~V}, 7 \mathrm{~V}, 9 \mathrm{~V}$ and $12 \mathrm{~V}$ behaved as susceptible or efficient host and the other clones were resistant or non-efficient host.
\end{abstract}

Key words: Coffea canephora, clones, robust coffee, resistance, root-knot nematode.

\section{RESUMEN}

Entre los factores que limitan la productividad de los cultivos de café en Brasil son las enfermedades, especialmente el nematodo Meloidogyne exigua presenta relevancia. El objetivo de este estudio fue evaluar la resistencia de 13 clones $(1 \mathrm{~V}, 2 \mathrm{~V}, 3 \mathrm{~V}, 4 \mathrm{~V}, 5 \mathrm{~V}, 6 \mathrm{~V}$, $7 \mathrm{~V}, 8 \mathrm{~V}, 9 \mathrm{~V}, 10 \mathrm{~V}, 11 \mathrm{~V}, 12 \mathrm{~V}$ y 13V) que comprenden la variedad clonal de café Conillón "Vitoria INCAPER 8142 " (Coffea canephora Pierre), a M. exigua. Clones y un testigo (C. arabica cv. Catuai IAC-44) se inocularon con 7.000 individuos (huevos + juveniles) de M. exigua. Después de 180 días de la inoculación se determinó la población final de nematodos por planta. Para determinar los niveles de resistencia se consideró el factor de la reproducción y el Indice de reproducción. El cultivar "Victoria INCAPER 8142" mostró clones con diferentes niveles de resistencia. Los clones $1 \mathrm{~V}, 4 \mathrm{~V}, 7 \mathrm{~V}, 9 \mathrm{~V}$ e $12 \mathrm{~V}$ se comportaron como huésped susceptible y eficiente, y los otros clones fueron anfitriones menos resistentes o ineficientes.

Palabras clave: Coffea canephora, clones, café robusta, resistencia, nematodo de las agallas.

\section{Introduction}

The coffee is affected by many diseases such as rust, brown eye spot, phoma leaf spot, etc., which have been the subject of many studies, however, the nematodes have received little attention, although they may limit the exploitation of this important crop (Gonçalves and Silvarolla, 2001).

The phytonematodes, usually present in soil, feed on the roots of plants causing direct damage by destroying cells and tissues and indirect damages for opening gateways to other pathogens (Ventura et al., 2007). Among the species that affect the coffee (Coffea canephora Pierre and Coffea arabica L.), Meloidogyne exigua Goeldi, 1887, is the most widespread in the Americas and is present in the main coffee regions, causing yield losses (Carneiro and Almeida, 2000).

In infested areas with $M$. exigua, one of the most desirable management is the use of resistant cultivars.

1 Federal University of Espirito Santo, Departamento of Plant Produciton, 29500-000, Alegre, ES, Brazil. Alto Universitário, s/n, Centro, C.P.16, CEP 29.500-000, Alegre-ES.

2 Instituto Capixaba de Pesquisa, Assistência Técnica e Extensão Rural, INCAPER, Vitória-ES, Rua Afonso Sarlo, 160 - Bento Ferreira, Vitória-ES, 29050-790.

* Corresponding author: fabio.alves@ufes.br

Fecha de Recepción: 1 Noviembre, 2011.

Fecha de Aceptación: 27 Noviembre, 2013. 
Some genotypes have the ability to reduce the rate of reproduction of $M$. exigua, leading to continued declines in the pathogen population (Roberts, 2002). This resistance has been identified in the cultivar IAC 2258 Apoatã of $C$. canephora (Salgado et al., 2005). In a few years the clonal cultivar of konillon coffeetrees 'Victoria INCAPER 8142' was developed, formed by a group of thirteen superior clones. This variety stands out from others because it has high productivity, yield stability, tolerance to drought and rust, uniformity of maturity and large grains size (Ferrão et al., 2007). However, it's unknown the level of resistance of this cultivar to M. exigua, which restricts its cultivation in contaminated areas with this Meloidogyne species.

For conilon coffee, the Instituto Capixaba de Pesquisa, Assistência Técnica e Extensão Rural (INCAPER) developed and recommended six varieties of coffee conilon, five of clonal propagation (EMCAPA 8111, EMCAPA 8121, EMCAPA 8131, EMCAPA 8141 - Robustão capixaba and Victoria - INCAPER 8142) and one of seed propagation (EMCAPA 8151 - Robusta Tropical) (Ferrão et al., 2007). These varieties have genetic variability for resistance to diseases, the clonal varieties especially and the most productive clones (Ventura et al., 2007). However is need for studies to evaluate the performance of these varieties and clones against $M$. exigua.

Although there's tendency of $C$. canephora to show greater resistance to M. exigua, compared to C. arabica species (Curi et al., 1970), this resistance is very dependent on the genotype, being necessary a genetic evaluation for further conclusions. If the reproductive rate of $M$. exigua in each clone is quantified, it is possible to identify those clones that can inhibit the pathogen.

This study aimed to evaluate the level of resistance of the thirteen clones that make up the clonal cultivar of coffee-trees konillon Vitoria 8142 INCAPER against M. exigua and identify those with greatest effect on the reproductive rate of the pathogen.

\section{Material and Methods}

The experiment was carried out from 7 august to 8 march in a greenhouse at the Centro de Ciências Agrárias da Universidade Federal do Espírito Santo (CCA-UFES), Alegre (ES), $20^{\circ} 45^{\prime} \mathrm{S}$ and $41^{\circ} 29^{\prime}$ $\mathrm{W}$ and $270 \mathrm{~m}$ altitude. It was evaluated the 13 clones that make up the cultivar of coffee conilon (C. canephora Pierre) Vitoria INCAPER 8142. The cultivar Catuaí-IAC 44 (C. Arabica L.) was used as susceptibility standard (control). The treatments were arranged in a completely randomized design with seven replicates.

Coffee seedlings were produced in the INCAPER and sent to the CCA-UFES in aseptic conditions. When the plants reach the 3rd pair of leaves, they were transferred to a plastic bag containing $12 \mathrm{dm}^{3}$ of a mixture of soil and sand at a ratio of $2: 1(\mathrm{~V}: \mathrm{V})$ previously treated in autoclave $\left(140^{\circ} \mathrm{C} / 1\right.$ hour on three consecutive days). Thirty days later each plant was inoculated with 7,000 nematodes $(75 \%$ eggs + $25 \%$ second-stage juveniles).

To obtain the inoculum, a pure population of M. exigua was multiplied and was maintained on roots of $C$. arabica cv. IAC-44 b cultivated in 5-liter pots containing a mixture of soil and sand $(1: 1 \mathrm{~V}$ : V) previously autoclaved, as described before, and maintained in a greenhouse. Employing the technique of Hussey \& Barker (1973), modified by Boneti \& Ferraz (1981), the inoculum was extracted from the roots of plants and was quantified in Peters chamber under stereoscope. Subsequently, an aliquot of a aqueous suspension of nematodes in three holes made in the soil around the plants was deposited. The fertilizations were based on soil analysis. To have an adequate nutrition of plants, two foliar spray applications of calda viçosa were made. The plants were cultivated with only one orthotropic branch and irrigation was carried out when was necessary. With a automatic weather station the air temperature during during the experimental period was recorded.

180 days after inoculation, the plants were removed from the pots, the roots carefully washing to remove the substrate and determined the final nematode population (FP) at each root system (Bonetti and Ferraz, 1981).Subsequently, we calculated the reproduction factor of the nematodes (RF) by dividing the value of the population final (FP) by the value of the initial population (IP) of each treatment $(\mathrm{RF}=\mathrm{FP} / \mathrm{IP})$.

Levels cultivar resistance to nematodes were classified using two criteria.The first, adopted by Seinhorst (1967), in which plants with RF $>1$ are considered efficient host (EH), RF $<1$ non-efficient host (NEH), and RF $=0$ non host $(\mathrm{NH})$. In the second criteria, the reproduction factor (RF) was calculated dividing final population of each genotype by initial population $(\mathrm{RF}=\mathrm{Fp} / \mathrm{Ip})$. The resistance selection was based on criterion proposed by Moura \& Regis (1987) (Table 1). 
Table 1. Criterion to evaluate percentage of the reproduction rate (\%RR) adopted from Moura \& Regis (1987).

\begin{tabular}{cl}
\hline$\%$ RR & \multicolumn{1}{c}{ Host reaction } \\
\hline $0-25$ & Highly susceptible (HS) \\
$26-50$ & Susceptible (SU) \\
$51-75$ & Low resistant (LR) \\
$76-95$ & Moderately resistant (MR) \\
$96-99$ & Resistant (RE) \\
100 & Highly resistant (HR) or immune (IM) \\
\hline
\end{tabular}

\section{Results and Discussion}

Based on the criterion used by Moura and Regis (1987), clones $3 \mathrm{~V}, 5 \mathrm{~V}, 8 \mathrm{~V}$ and $13 \mathrm{~V}$ showed higher $\%$ RR $(71.87 ; 72.32 ; 74.55$ and 75 , respectively), behaving as LR. The clones $2 \mathrm{~V}, 6 \mathrm{~V}, 10 \mathrm{~V}$ and $11 \mathrm{~V}$ also were LR. The other clones were classified as SU to M. exigua (Table 2). All clones that behaved as SU and PR by the criterion of Moura and Regis (1987) were EH and NEH, respectively, according Seinhorst (1967), demonstrating consistency between the two methods.

None of the clones behaved as MR, RE, HR or IM, demonstrating that exist a few resistance genes to these materials, and if these clones are grown in an area with root-knot nematode may be subject to damages and losses yield caused by these plant parasitic nematodes (Potter and Olthof , 1974; Chen et al., 1999; Chen et al., 2000; Castillo et al., 2006).

Some authors have reported that there is resistance in the species $C$. canephora, C. congensis, $C$. dewevrei, C. liberica. C. racemosa and $C$. salvatrix against M. exigua (Fazuoli and Lordello, 1977, 1978), but there are few works that allude to the resistance in C. canephora (Fazuoli et al. 2005; Matiello et al., 2005) although plants resulting from crosses between different species of Coffea show resistance to M. exigua (Sakiyama et al., 1999). Fazuoli et al, (1977), tried to find out sources of resistance to $M$. exigua in populations derived from interspecific crosses (Coffea arabica $\mathrm{x}$ C. canephora and $C$. arabica $\mathrm{x} C$. dewevrei). According to this study, of 1,692 seedlings analyzed, only 106 were selected for not presenting nematode galls.

In another work, Fazuoli and Lordello (1978) evaluated several plant species and cultivars of coffee for resistance to M. exigua and reported nematode reproduction was affected due to the resistance of $C$. canephora.Silva et al. (2007) also studied the effect of populations of M. exigua in 25 genotypes from the Timor Hybrid, natural crossing between $C$. arabica

Table 2. Final population (FP), reproduction factor (RF), percentage of the reproduction rate (\%RR) and reaction (RE) of clones of the variety Vitória INCAPER 8142 for resistance to M. exigua in an experiment carried out in Alegre-ES, 2007.

\begin{tabular}{|c|c|c|c|c|c|}
\hline Clones & FP & $\mathrm{RF}^{1}$ & $\% \mathrm{RR}^{2}$ & $\mathrm{RMR}^{3}$ & $\mathrm{RSE}^{4}$ \\
\hline Clone 1V & $9,142.86$ & 1.3 & 41.96 & SU & EH \\
\hline Clone 2V & $6,187.71$ & 0.88 & 60.71 & LR & $\mathrm{NEH}$ \\
\hline Clone 3V & $4,387.29$ & 0.63 & 71.87 & LR & $\mathrm{NEH}$ \\
\hline Clone 4V & $10,928.57$ & 1.56 & 30.36 & SU & EH \\
\hline Clone 5V & $4,333.29$ & 0.62 & 72.32 & LR & $\mathrm{NEH}$ \\
\hline Clone 6V & $5,642.86$ & 0.81 & 63.84 & LR & $\mathrm{NEH}$ \\
\hline Clone 7V & $13,125.71$ & 1.87 & 16.52 & SU & $\mathrm{EH}$ \\
\hline Clone 8V & 4,000 & 0.57 & 74.55 & LR & $\mathrm{NEH}$ \\
\hline Clone 9V & $11,581.57$ & 1.65 & 26.34 & SU & EH \\
\hline Clone 10V & $6,901.43$ & 0.99 & 55.80 & LR & $\mathrm{NEH}$ \\
\hline Clone $11 \mathrm{~V}$ & $6,071.43$ & 0.87 & 61.16 & LR & $\mathrm{NEH}$ \\
\hline Clone $12 \mathrm{~V}$ & $7,833.29$ & 1.12 & 50 & $\mathrm{SU}$ & $\mathrm{EH}$ \\
\hline Clone 13V & $3,928.57$ & 0.56 & 75 & LR & $\mathrm{NEH}$ \\
\hline Control & $15,681.43$ & 2.24 & - & SU & EH \\
\hline Average & $7,235.74$ & 1.03 & 54.02 & - & - \\
\hline
\end{tabular}

${ }^{1} \mathrm{RF}$ = final population/initial population.

$2 \% \mathrm{RR}=(\mathrm{RF}$ control $-\mathrm{RF}$ clone $) / \mathrm{RF}$ control $\mathrm{x} 100$.

${ }^{3}$ Reaction of the clones according to the criterion of Moura and Regis (1987). Highly susceptible (HS); susceptible (SU); low Resistant (LR); moderately resistant (MR); Resistant (RE); highly resistant (HR) or immune (IM).

${ }^{4}$ Reaction of the clones based on the criterion of Seinhorst (1967). RF $<1$ - non-efficient host (NEH), RF $>1$ - efficient host (EH) and $\mathrm{RF}=0-$ non host $(\mathrm{NH})$. 
and C. canephora, and their derivatives: Catimor (Caturra X Híbrido de Timor) Cavimor (Catuaí X Catimor) Sarchimor (Villa Sarchi X Hibrido de Timor) and Icatu (artificial crossing between $C$. Arabica X C. canephora). Among these materials $56 \%$ were susceptible to the nematode.

It is important to note that the reaction of the coffee plants may be different to isolates of M. exigua coming from different regions. Ribeiro et al. (2005), for example, evaluated the reaction of progenies in C. canephora interspecific hybrids timor UFV 1680 40828 Cad, UFV 1804 428-3, UFV 1285 382-09 Cad, UFV 1805 428-5, UFV 1825 433-11 Cad and progenies of Catimor UFV $66171246 \mathrm{Col}$. Am., UFV 6572698 Col., UFV 6569575 Col., UFV $66191322 \mathrm{Col}$ am. to a M. exigua population come from Mirai, MG that were SU. However, Gonçalves and Pereira (1998), assessing the reaction of these selections to a population of M. exigua, from São Sebastião do Paraíso, MG, obtained reaction of resistance. According to Silva et al. (2007) there is evidence of the existence of intraspecific variability in $M$. exigua in relation to virulence in coffee plants. In fact, in addition to the wide distribution and damage in coffee, another aggravating of $M$. exigua is the genetic variability, demonstrated by different results in coffee plants inoculated with different populations of this nematode (Ribeiro et al., 2005, Barbosa et al., 2007). Muniz et al. (2007), for example, found virulence in resistant coffee plants carrying the gene Mex-1 inoculated with a fluminense population of M. exigua.

Considering the importance of clonal variety Vitória INCAPER 8142 in the scenario of coffee culture, further research should be performed to confirm the results, since the resistance to nematodes is dependent on many factors (Ventura et al., 2007). These studies must be carried out under controlled environment and, after confirmation of the resistant clones, they should be evaluated under field conditions at different levels of infestation and populations of $M$. exigua, once the characterization of variability in M. exigua is essential to direct the work of coffee breeding.

\section{Acknowledgements}

The authors acknowledge Fundação de Amparo à Pesquisa do Estado do Espírito Santo (FAPES) for the financial support (protocol $N^{\circ} 38939754 / 2007$ ).

\section{Literature Cited}

Alves, F. R.; Freitas, L.G.; Martinelli, P.R.P.; Ferraz, S.; Maffia, L.A. 2008. Influence of Inoculum densities of Meloidogyne spp. and Host plant age on the mass production of Pasteuria penetrans. Nematologia Brasileira, 32(1): 13-19.

Barbosa, D.H.S.G.; Vieira, H.D.; Souza, R.M.; Dias, P.P.; Viana, A.P.

2007. Desenvolvimento vegetativo e reação de genótipos de Coffea spp. a uma população de Meloidogyne exigua virulenta a cultivares resistentes. Nematologia Brasileira, 31 (1): 01-06.

Boneti, J.I.; Ferraz, S.

1981. Modificações do método de Hussey and Barker para extração de ovos de Meloidogyne exigua em raízes de cafeeiro. Fitopatologia Brasileira, 6: 533 (Resumo).

Carneiro, R.M.D.G.; Almeida, M.R.A.

2000. Distribution of Meloidogyne spp. on coffee in Brazil: identification, characterization and intraspecific variability. In: Mejoramiento sostenible del café arabica por los recursos genéticos, asistido por los marcadores moleculares, com énfasis en la resistencia a los nemátodos, 2000, Turrialba, Costa Rica, Publicación Especial. CATIE / IRD, pp. 43-48.

Carneiro, R.M.D.G., Costa, S.B.; Sousa, F.R.; Santos, D.F.; Almeida, M.R.A.; Santos, M.F.A.; Siqueira, K.M.S.; Tigano, M.S.; Fonseca, A.F.A.

2009. Reação de cafeeiros 'conilon' a diferentes populações de Meloidogyne spp. Anais do VI Simpósio de Pesquisa dos Cafés do Brasil. CD-ROM.
Castillo P.; Landa, B.B.; Navas-Cortés, J.A.

2006. First Report of Meloidogyne arenaria Parasitizing LeUuce in Southern Spain. Plant disease. 90 (7): 975.

Chen J.; Abawi G.S.; Zuckerman, B.M.

2000. Efficacy of Bacillus thuringiensis, Paecilomyces marquandii and Streptomyces costaricanus with and without Organic Amendments against Meloidogyne hapla Infecting Lettuce. Journal of Nematology. 32 (1): 70-77.

Chen J.; Abawi, G.S.; Zuckerman, B.M.

1999. Suppression of Meloidogyne hapla and its damage to lettuce grown in a mineral soil amended with chitin and biocontrol organisms. Supplement to the Journal of Nematology. 31 (4S): 719-725.

Curi, S.M.; Carvalho, A.; Moraes, F.P.; Mônaco, L.C.; Arruda, H.V. 1970. Novas fontes de resistência genética de Coffea no controle do nematóide do cafeeiro, Meloidogyne exigua. O Biológico. 36 (10): 293-295.

Fazuoli, L.C.; Gonçalves, W.; Braghini, M. T.; M. B. Silvarolla. 2005. Tupi RN IAC 1669-13: cultivar de café com resistência a Hemileia vastatrix e ao nematóide Meloidogyne exigua. In: Congresso Brasileiro de Pesquisas Cafeeiras, 31, 2005, Guarapari. Resumos. Rio de Janeiro: MAPA/PROCAFÉ/ PNFC, pp. 228-269.

Fazuoli, L.C.; Lordello, R.R.A.

1977. Resistência de Coffea liberica e C. dewevrei a Meloidogyne exigua. Sociedade Brasileira de Nematologia. Public. $\mathrm{N}^{\circ} 2$, pp. 197-199. 
Fazuoli, L.C.; Lordello, R.R.A.

1978. Fontes de resistência em espécie de cafeeiro ao nematóide Meloidogyne exigua. Sociedade Brasileira de Nematologia. 3: 49-52.

Ferrão, R.G.; Fonseca, A.F.A.; Ferrão, M.A.G.; Bragança, S.M.; Verdin Filho, A.C.; Volpi, P.S.

2007. Cultivares de café conilon. In: Ferrão, R.G; Fonseca, A.F.A.; Bragança, S.M.; Ferrão, M.A.G.; Muner, L.H.D. Café Conilon. Incaper, pp. 203-226.

Gonçalves, W.

1997. Resistência do cafeeiro a Meloidogyne spp. Fitopatologia Brasileira, 22: 230 (Abstract).

Gonçalves, W.; Silvarolla, M.B.

2001. Nematóides parasitos do cafeeiro. In: Zambolim, L. (Org.). Tecnologias de Produção de Café com Qualidade, pp. 199-267.

Gonçalves, W.; Pereira, A.

1998. Effect of inoculum levels in the early evaluation of coffee reaction to Meloidogyne exigua. Nematologia Brasileira. 22 (1): 75-78.

Lordello, R.R.A.; Lordello, A.I.L.

1987. Avaliação da resistência de cafeeiros às raças de Meloidogyne incognita. Bragantia, Campinas, 46 (1): 59-64.

Matiello, J.B.; Santinato, R.; Garcia, A.W.R.; Almeida, S.R.; Fernandes, D.R.

2005. Cultura de café no Brasil: Novo manual de recomendações. Edição 2005. Revisada, ampliada $e$ ilustrada. Rio de Janeiro: Fundação Procafé, 434 pp.

Moura, R.M.; Regis, E.M.O.

1987. Reação de cultivares de feijoeiro comum (Phaseolus vulgaris) em relação ao parasitismo de Meloidogyne javanica e $M$. incognita (Nematoda: Heteroderidae). Nematologia Brasileira, 11: 215-225.

Muniz, M.F.S.; Campos, V.P.; Moita, A.W.; Gonçalves, W.; Carneiro, R.M.D.G.

2007. Reação de genótipos de cafeeiro a populações de Meloidogyne exigua: detecção de virulência natural ao gene Mex-1. In: Congresso Brasileiro de Nematologia, 27, Goiânia. Resumos... Piracicaba, SP: SBN, pp. 84-85.

Oostenbrink, M.

1966. Major characteristics of the relation between nematodes and plants. Mededelingen Landbouhogeschool, 66 (4): 1-46.

Ploege, A.T.; Philips, M.S.

2001. Damage to melon (Cucumis melo L.) cv. Durango by Meloidogyne incognita in Southern California. Nematology, 3 (2): 151-157.
Potter, J.W.; Olthof, T.H.A.

1974. Yield losses in fall-maturing vegetables relative to population densities of Pratylenchus penetrans and Meloidogyne hapla. Phytopathology. 64: 1072-1075.

Ribeiro, R.C.F.; Pereira, A.A.; Oliveira, C.H.; Oliveira, R.D.L. 2005. Resistência de progênies de híbridos interespecíficos de Coffea arabica e Coffea canephora a Meloidogyne exigua. Nematologia Brasileira, Piracicaba, 29 (1): 11-16.

Ribeiro, R.C.F.; Pereira, A.A.; Oliveira, C.H.; Lima, R.D. 2005. Resistência de progênies de híbridos interespecíficos de Coffea arabica e Coffea canephora a Meloidogyne exigua. Nematologia Brasileira, 29 (1): 11-16.

Roberts, P.A.

2002. Concepts and consequences of resistance. In: Starr, J. L.; Cook, R.; Bridge, J. (ed.). Plant resistance to parasitic nematodes, CAB International, pp. 23-41.

Ronchi, C.P.; Damatta, F.M.; Batista, K.D.; Moraes, K.D; Loureiro, M.; Ducatti, C.

2006. Growth and photosynthetic down-regulation in Coffea arabica in response to restricting root volume. Functional Plant Biology, 33 (11): 1013-1023.

Salgado, S. M.; Resende, M.L.V.; Campos, V.P.

2005. Reprodução de Meloidogyne exigua em cultivares de cafeeiros resistentes e suscetíveis. Fitopatologia brasileira, 30 (4): 413-415.

Sasser, J.N.; Carter, C.C.; Hartman, K.M.

1984. Standardization of host suitab ility studies and reporting of resistance to root-knot nematodes. NCSU Graphics, Raleigh, NC, USA, 7 p.

Seinhorst, J.W.

1967. The relationships between population increase and population density in plant parasitic nematodes. I. Definitions of the terms host, host status and resistance. 4. The influence of external conditions on the regulation of population density. Nematologica, 13 (3): 429-50.

Silva, R.V., Oliveira, Rosângela D.L.; Pereira A.A.; Sêni, D.J. 2007. Respostas de Genótipos de Coffea spp. a diferentes populações de Meloidogyne exigua Fitopatologia Brasileira, 32 (3): 205-212.

Ventura, J.A.; Costa, H.; Santana, E.N.; Martins, M.V.V. 2007. Diagnóstico e manejo das doenças do cafeeiro conilon. In: Ferrão, R. G.; Fonseca, A.F.A.; Bragança, S.M.; Ferrão, M.A.G.; Muner L.H. (ed.). Café Conilon. Vitória, ES: Incaper, pp. 481-483. 
